\title{
Hepatitis B and C viral infection: prevalence, knowledge, attitude and practice among barbers and clients in Gharbia governorate, Egypt
}

S. Shalaby, ${ }^{1}$ I.A. Kabbash, ${ }^{1}$ G. El Saleet, ${ }^{1}$ N. Mansour, ${ }^{1}$ A. Omar ${ }^{1}$ and A. El Nawawy ${ }^{2}$

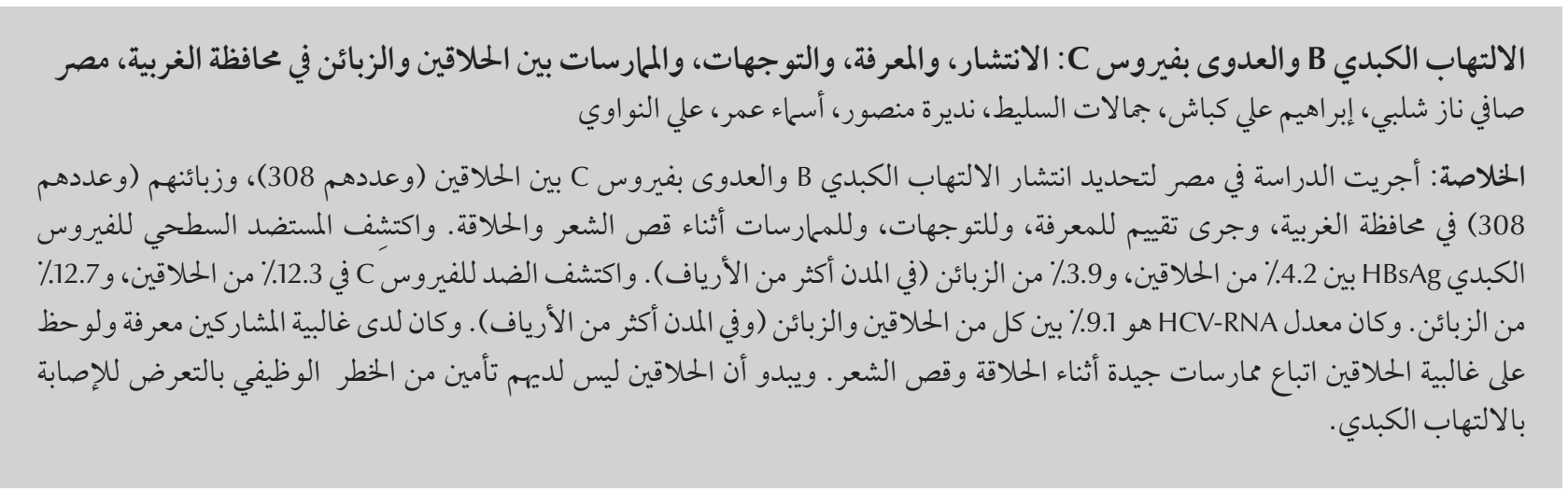

ABSTRACT A study in Egypt determined the prevalence of hepatitis B and C virus infections among barbers ( $n=$ 308 ) and their clients $(n=308)$ in Gharbia governorate, and assessed knowledge, attitude and practices during hair-cutting and shaving. HBsAg was detected among $4.2 \%$ of barbers and $3.9 \%$ of clients (more urban than rural). Anti-HC antibodies were detected in $12.3 \%$ of barbers and $12.7 \%$ of clients. HCV-RNA prevalence was $9.1 \%$ among both barbers and clients (more rural than urban). Knowledge was high among the majority of participants and good practices during shaving and hair-cutting were observed for the majority of barbers. Barbers appeared to have no job-related risk of acquiring viral hepatitis.

Infection par les virus de l'hépatite B et de l'hépatite C : prévalence, connaissances, attitudes et pratiques chez les coiffeurs pour hommes et leurs clients dans le gouvernorat de Gharbia (Égypte)

RÉSUMÉ Une étude réalisée en Égypte a déterminé la prévalence des infections par les virus de l'hépatite B (VHB) et de l'hépatite C (VHC) chez les coiffeurs pour hommes $(n=308)$ et leurs clients $(n=308)$ dans le gouvernorat de Gharbia, et évalué les connaissances, les attitudes et les pratiques pendant la coupe de cheveux et le rasage. L'antigène de surface (Ag HBs) du VHB a été détecté chez 4,2 \% des coiffeurs et 3,9\% des clients (plutôt citadins que ruraux). Des anticorps anti-HC ont été trouvés chez $12,3 \%$ des coiffeurs et $12,7 \%$ des clients. La prévalence de I'ARN du VHC était de 9,1 \% chez les deux groupes (plutôt ruraux que citadins). Les connaissances étaient élevées chez la plupart des participants et de bonnes pratiques ont été observées lors du rasage et de la coupe des cheveux chez la plupart des coiffeurs. Ceux-ci ne semblaient pas courir de risque de contracter une hépatite virale dans le cadre de leur travail. 


\section{Introduction}

Bloodborne diseases impose heavy burdens on national economies and individual families due to costs arising from acute and chronic morbidity and mortality. Globally, 2 billion people are infected with hepatitis B virus (HBV). An estimated 170 million persons are chronically infected with hepatitis $\mathrm{C}$ virus $(\mathrm{HCV})$ and 3-4 million persons are newly infected each year $[1,2]$.

The highest $\mathrm{HCV}$ prevalence in the world is in Egypt, where the prevalence of infection increases steadily with age. High rates of infection are observed among all age groups although there are regional differences in the average overall prevalence $[3-5]$. The prevalence ranges from $10 \%$ to $20 \%$ of the general population, and rural populations show a higher prevalence than urban ones. This difference has been attributed to past infection and treatment of schistosomiasis [6-8].

The barber shop is a place where haircutting, shaving and hair reforming for men are practised. Negligence during the use of sharp instruments may be a risk factor for bloodborne infections, causing serious health problems for both the barber and the clients [9]. Razor sharing and shaving in barber shops has been identified as a key risk factor for HBV infection in Italy [10]. It has also been identified as a risk factor for $\mathrm{HCV}$ among institutionalized patients [11].

The objectives of this study were to determine the prevalence of both HBV and $\mathrm{HCV}$ infections among barbers and a sample of their clients in Gharbia governorate, Egypt, and to assess the knowledge and attitude of the study population regardingviral hepatitis and their practices during hair cutting and shaving.

\section{Methods}

\section{Study setting}

This study was carried out during the year 2007 in Gharbia governorate, one of the governorates of the Nile Delta area. Two out of 8 administrative areas of the governorate were randomly chosen as the study location (Tanta and Mahalla El-Koubra). The 2 cities (Tanta and Mahalla El-Koubra) were included to represent urban localities, while 3 villages (from 42 villages related to Tanta and 55 villages related to $\mathrm{Ma}$ halla) were selected randomly from the list of total villages to represent rural localities. Gharbia governorate has a population of nearly 3 million, with an urban to rural ratio of residents of 1:2.

\section{Sample}

The target population of the study was people working in barber shops and practising hair-cutting and shaving and 1 regular client from each shop who had attended for at least 1 year.

Based on the lowest reported prevalence of $3 \%$ for hepatitis B surface antigen (HBsAg), the sample size that could detect a prevalence ranging from $1 \%-5 \%$, at a $95 \%$ confidence level, was estimated as 280 in each group (barbers and clients). In fact 616 subjects (308 barbers and 308 clients) were enrolled as follows. All barbers in the chosen 6 villages who agreed to participate in the study were included (a total of 147 barbers out of 159 barbers) and the same number of clients, plus a total of 161 barbers from urban areas in both Tanta and Mahala cities and the same number of clients. The proportion of individuals who refused to participate ranged from $4 \%$ to $8 \%$ at different localities of the study. Efforts were made to explain the objectives of the study and its benefits to the participating person and the whole community in order to minimize refusals, which were mainly due to fears about discovering their serostatus or giving a blood sample.

A block sampling technique with a map was used. Regarding the urban areas, a multistage random sample was used. Both Tanta and Mahalla ElKoubra cities were classified into 2 large strata, based on the socioeconomic standard of the dwellings (high and medium-low). Each stratum was further divided into clusters and 5 clusters were chosen randomly from each stratum. A list of barber shops in the study areas was prepared with the help of senior barbers living in the study area. Direct personal communication with barbers in their working shop was made to get their consent and cooperation before being enrolled in the study. While collecting data from the barber, one of the attending clients at that time was approached and invited to participate in the study after the purpose of the study was explained. In case of refusal by the client another person was chosen in the same setting.

\section{Data collection}

A pre-designed, structured questionnaire sheet was filled inside the barber shop through direct personal interview with both the barber and the client. Direct observation of the place and the practice of the barber during his work were also carried out. The questionnaire sheet included the following data: sociodemographic data; knowledge, awareness and beliefs related to HBV and HCV infection; attitude to HBV and $\mathrm{HCV}$; risky behaviours that might contribute to infection with both types of hepatitis; and an observational checklist for barbers' practice during hair-cutting/shaving. The cut-off for a high level knowledge was defined as $>50 \%$ of questions correct.

Before starting data collection the research team reviewed thoroughly the questionnaire and received an orientation training on communication skills and were trained on the methods of data collection. The validity of the questionnaire was tested by expert and peer review and the reliability was tested by the test-retest method in a pilot study including 30 barbers and 30 clients not included in the study sample.

A blood sample $(5 \mathrm{~mL})$ was taken from each study subject through 
venepuncture using a vacutainer device. The sample was allowed to clot naturally to separate the serum for analysis and was stored upright in an ice box/ refrigerator at a temperature of $2-8{ }^{\circ} \mathrm{C}$ (for up to 3 days) until it was sent to the laboratory for analysis.

For diagnosis of $\mathrm{HBV}$ infection, an in vitro diagnostic kit for the detection of HBsAg in human serum was used (Biorex Diagnostics, UK). This test is an enzyme-immunoassay based on a "sandwich" principle.

For diagnosis of HCV, a 3rd-generation enzyme-linked immunosorbent assay (ELISA) kit for qualitative detection of antibodies to HCV in human serum or plasma was used (Biorex Diagnostics, UK). Samples found to be negative on the preliminary screening were considered $\mathrm{HCV}$-seronegative. Initially positive and borderline samples were confirmed by qualitative HCV-RNA detection assays using classic polymerase chain reaction using a commercial kit (HEPA-Check-C, Nuclear Laser Medicine, Italy).

Standard techniques were applied according to the manufacturer's guidelines. Laboratory investigations were carried out in a specialized private laboratory (Al-Ahram Laboratory, Tanta).

\section{Ethical considerations}

The people recruited to the study were informed about the objectives of the study and that they were free to refuse participation. A verbal witnessed consent was obtained from each study participant. Clients or barbers $<18$ years old were not included in the study as they were unable to give legal consent. The confidentiality of collected data and for the results of investigations was assured. Only the principal investigator held the results of blood samples tested. The participants were informed about their $\mathrm{HBV} / \mathrm{HCV}$ test results if they expressed a desire to be informed. These results were delivered in person in a sealed envelope.

\section{Statistical analysis}

The collected data were organized, tabulated and statistically analysed using SPSS, version 12. The chi-squared test was used for testing the significance of differences between the study groups. When the chi-squared test was not appropriate, Fisher exact test was used. The level of significance was 5\%.

\section{Results}

A total of 616 subjects (308 pairs of barbers and clients) were included: 322 from urban areas (161 pairs) and 294 from rural settings (147 pairs).

The majority of the study subjects ( $64.3 \%$ of barbers and $59.4 \%$ of clients) were aged $20-40$ years. Nearly one-half of barbers (49.7\%) and $41.2 \%$ of clients had intermediate education. About one-third of clients (36.7\%) were highly educated compared with only $7.8 \%$ of barbers.

HBsAg was detected in 25 individuals (13 barbers and 12 clients), an overall prevalence of $4.1 \%$. The rate was similar among barbers and clients $(4.2 \%$ versus 3.9\%) (Table 1). The prevalence of HBsAg among urban barbers and clients was higher than that among rural ones (6.2\% versus $2.0 \%)$, although not significantly so. Anti-HCV antibodies were detected in 77 individuals with an overall prevalence of $12.5 \%$. Again, the rate was almost the same among barbers and their clients (12.3\% versus $12.7 \%)$. The infection rate was highest among rural clients (13.6\%) followed by rural barbers (12.3\%). The prevalence of anti-HCV was equal among urban barbers and their clients (11.8\%). Detection of HCV-RNA revealed similar figures among both barbers and clients (9.1\%). The prevalence in rural subjects was higher than that of urban subjects (10.2\% and $8.1 \%$ respectively). Double infection was detected in 3 subjects (1 barber and 2 clients). There was no statistically significant difference between barbers and clients in the rate of HBV or HCV infection (Table 1).

The level of knowledge about modes of transmission was high among the majority of the study participants (over $80 \%$ for most questions). Knowledge about the existence of protective drugs and vaccines was to low; about $40 \%$ knew about the presence of an HBV vaccine and around one-quarter claimed to know about a protective vaccine for $\mathrm{HCV}$. Friends and relatives were the main source of information for both barbers (46.1\%) and clients (49.7\%), followed by television, newspapers and doctors (Table 2).

About two-thirds of the barbers (67.9\%) and more than half of the clients $(55.5 \%)$ were concerned about the status of shaving blades used ( $P$ $=0.002)$ (Table 3$)$. Positive attitudes towards antiseptic use after shaving and safe injections was found among 55.8\% and $49.0 \%$ of barbers compared with $70.5 \%$ and $66.9 \%$ of clients respectively $(P<0.001)$. It was also found that 217 (70.5\%) of the barbers would not mind being tested for viral hepatitis and 145 (47.1\%) would be willing to have periodic screening for viral hepatitis and other bloodborne diseases.

The practice of barbers during shaving showed that changing the blade for each client was the practice of 291 barbers (94.5\%); $93.2 \%$ of urban and $95.9 \%$ of rural ones. Disinfection of used instruments was practised by $76.9 \%$ and washing hands by $63.0 \%$ of them. Wearing protective clothes, especially gloves, was practised by $52.8 \%$ of urban barbers and only $9.6 \%$ of rural ones. The difference between rural and urban barbers regarding these practices was not statistically significant, except for wearing protective clothes/gloves and washing used instruments $(P<0.001)$ (Table 4).

The shaving practices of the clients revealed that the practice of urban clients was better than that of rural ones regarding verification of the status of 


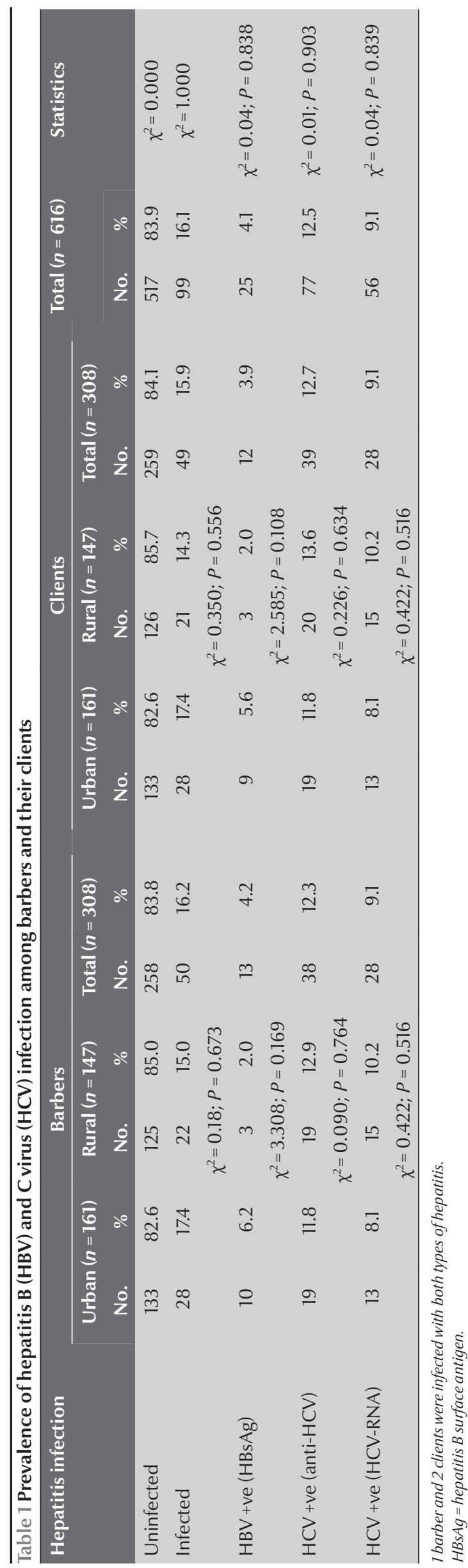

used instruments before shaving $(P<0.001)$, bringing their own instruments $(P=0.019)$ and asking the barber to wash his hands before shaving $(P=0.012)$. The practice of rural clients was better regarding refusing shaving with used instruments $(P<0.001)$ and asking the barber to disinfect used instruments (but not statistically significant) (Table 5).

On observing barber's shops and their practice during shaving it was found that, in general, the majority of shops were well-equipped, clean and neat. Rural shops were significantly better than urban shops regarding the electric supply and ventilation while urban shops were better regarding the presence of washing facilities and good decoration. Observations during shaving revealed that using a razor machine, throwing used blades in the waste bin and disinfection of skin cuts were practised by more than three-quarters of barbers with a significantly higher rate of use of a razor machine among urban compared with rural barbers $(P<0.001)$. Using alum as antiseptic for skin cuts was practised by a higher percentage of urban than rural barbers, while rural clients were more likely to change the blade for each client $(P<0.001)$ (Table 6).

\section{Discussion}

The prevalence of HBV and HCV infection has been widely investigated in many occupational groups, but few data are available on the prevalence in barber shops. Therefore, this study may fill a gap.

The prevalence of $\mathrm{HBs} \mathrm{Ag}$ has been reported to range from 3\% to $11 \%$ in Egypt [12]. In the present study, the total prevalence of HBsAg detected was $4.1 \%$, which is near the lower limit of the recorded national range. This rate is lower than that reported among barbers in Turkey (8.5\%) [13], but higher than among barbers in Morocco where HBV was found in only $2 \%$ of 150 barbers [14].

Qirbi et al. stated that HBV is generally associated with poor socioeconomic conditions [15]. However, the present study revealed that $\mathrm{HBsAg}$ was more prevalent among urban barbers and clients, who may be assumed to be of higher social class, than rural subjects. In contrast, our study revealed a higher prevalence of $\mathrm{HCV}$ infection among barbers and clients of rural areas than urban ones. These results are similar to the findings of previous studies among the general population that attribute the higher figures in rural areas to the endemicity of schistosomiasis and the use of glass syringes for parenteral treatment in the past decades. In addition, these studies observed that the seroprevalence rates of $\mathrm{HCV}$ were much higher in villages in the Nile Delta region compared with Upper Egypt and this was correlated with the difference in schistosomiasis infection rates in both regions $[16,17]$. Other workers assume that schistosomiasis-induced immune 


\begin{tabular}{|c|c|c|c|c|c|c|c|c|}
\hline \multirow[t]{2}{*}{ Knowledge item } & \multicolumn{2}{|c|}{ Barbers $(n=308)$} & \multicolumn{2}{|c|}{ Clients $(n=308)$} & \multicolumn{2}{|c|}{ Total $(n=616)$} & \multirow[t]{2}{*}{$x^{2}$-value } & \multirow[t]{2}{*}{$P$-value } \\
\hline & No. & $\%$ & No. & $\%$ & No. & $\%$ & & \\
\hline \multicolumn{9}{|l|}{ General awareness } \\
\hline Ever heard about liver diseases & 268 & 87.0 & 284 & 92.2 & 552 & 89.6 & 3.92 & $0.048^{*}$ \\
\hline Ever heard about viral hepatitis B \& C & 265 & 86.0 & 250 & 81.2 & 515 & 83.6 & 2.32 & 0.128 \\
\hline \multicolumn{9}{|l|}{ Knew modes of transmission } \\
\hline Blood transfusion & 285 & 92.5 & 290 & 94.2 & 575 & 93.3 & 0.42 & 0.518 \\
\hline Reusing needles & 279 & 90.6 & 289 & 93.8 & 568 & 92.2 & 1.83 & 1.176 \\
\hline Dental procedures & 261 & 84.7 & 275 & 89.3 & 536 & 87.0 & 2.43 & 0.119 \\
\hline IV drug use & 271 & 88.0 & 262 & 85.1 & 533 & 86.5 & 0.89 & 0.345 \\
\hline Scissors/surgical instruments & 256 & 83.1 & 271 & 88.0 & 527 & 85.5 & 2.57 & 0.109 \\
\hline Barbers shaving instruments & 239 & 77.6 & 254 & 82.5 & 493 & 80.0 & 1.99 & 0.158 \\
\hline Ear/body piercing & 205 & 66.6 & 230 & 74.7 & 435 & 70.6 & 4.51 & $0.034^{*}$ \\
\hline Sexual contact & 203 & 65.9 & 217 & 70.5 & 420 & 68.2 & 1.26 & 0.261 \\
\hline Tattooing & 196 & 63.6 & 223 & 72.4 & 419 & 68.0 & 5.04 & $0.025^{*}$ \\
\hline Sharing utensils & 150 & 48.7 & 167 & 54.4 & 317 & 51.5 & 1.66 & 0.197 \\
\hline Food & 114 & 37.0 & 126 & 40.9 & 240 & 39.0 & 0.83 & 0.363 \\
\hline Water & 78 & 25.3 & 104 & 33.8 & 182 & 29.5 & 4.87 & $0.027^{*}$ \\
\hline Others & 103 & 33.4 & 56 & 18.2 & 159 & 25.8 & 17.94 & $0.001^{*}$ \\
\hline \multicolumn{9}{|c|}{ Complications/treatment of viral hepatitis } \\
\hline On liver & 43 & 14.0 & 64 & 20.8 & 107 & 17.4 & 4.52 & $0.033^{*}$ \\
\hline On general health & 32 & 10.4 & 33 & 10.7 & 65 & 10.6 & 0.02 & 0.895 \\
\hline Presence of HBV treatment & 55 & 17.9 & 57 & 18.5 & 112 & 18.2 & 0.01 & 0.917 \\
\hline Presence of vaccine for HBV & 125 & 40.6 & 138 & 44.8 & 263 & 42.7 & 0.96 & 0.328 \\
\hline Presence of HCV treatment & 111 & 36.0 & 89 & 28.9 & 200 & 32.5 & 3.27 & 0.071 \\
\hline Presence of vaccine for HCV & 81 & 26.3 & 73 & 23.7 & 154 & 25.0 & 0.42 & 0.515 \\
\hline \multicolumn{9}{|l|}{ Source of information } \\
\hline Friends \& relatives & 142 & 46.1 & 153 & 49.7 & 295 & 47.9 & 0.650 & 0.420 \\
\hline Television & 148 & 40.1 & 117 & 38.0 & 265 & 43.0 & 5.960 & $0.014^{*}$ \\
\hline Newspapers & 99 & 32.1 & 127 & 41.2 & 226 & 36.7 & 5.090 & $0.024^{*}$ \\
\hline Doctors & 76 & 24.7 & 109 & 35.4 & 185 & 30.0 & 7.910 & $0.005^{*}$ \\
\hline Radio & 61 & 19.8 & 74 & 24.0 & 135 & 21.9 & 1.370 & 0.245 \\
\hline Health care workers & 16 & 5.2 & 44 & 14.3 & 60 & 9.7 & 13.46 & $0.001^{*}$ \\
\hline Others & 47 & 15.2 & 15 & 4.9 & 62 & 10.1 & 17.12 & $0.001^{*}$ \\
\hline
\end{tabular}

${ }^{*} P<0.05$.

More than 1 answer was reported.

$\mathrm{IV}=$ intravenous.

\begin{tabular}{|c|c|c|c|c|c|c|c|c|}
\hline \multirow[t]{2}{*}{ Attitude item } & \multicolumn{2}{|c|}{ Barbers $(n=308)$} & \multicolumn{2}{|c|}{ Clients $(n=308)$} & \multicolumn{2}{|c|}{ Total $(n=616)$} & \multirow[t]{2}{*}{$x^{2}$-value } & \multirow[t]{2}{*}{$P$-value } \\
\hline & No. & $\%$ & No. & $\%$ & No. & $\%$ & & \\
\hline Concerned about status of used blades & 209 & 67.9 & 171 & 55.5 & 380 & 61.7 & 9.40 & $0.002^{*}$ \\
\hline Concerned about using antiseptics & 172 & 55.8 & 217 & 70.5 & 389 & 63.1 & 13.51 & $0.001^{*}$ \\
\hline $\begin{array}{l}\text { Concerned about using disposable } \\
\text { syringes }\end{array}$ & 151 & 49.0 & 206 & 66.9 & 357 & 58.0 & 19.43 & $0.001^{*}$ \\
\hline
\end{tabular}

* $P<0.05$. 


\begin{tabular}{|c|c|c|c|c|c|c|c|c|}
\hline \multirow[t]{3}{*}{ Practice item } & \multicolumn{4}{|c|}{ Barbers' residence } & \multirow{2}{*}{\multicolumn{2}{|c|}{ Total $(n=308)$}} & \multirow[t]{3}{*}{$x^{2}$-value } & \multirow[t]{3}{*}{$P$-value } \\
\hline & \multicolumn{2}{|c|}{ Urban $(n=161)$} & \multicolumn{2}{|c|}{ Rural $(n=147)$} & & & & \\
\hline & No. & $\%$ & No. & $\%$ & No. & $\%$ & & \\
\hline Changes the blade for each client & 150 & 93.2 & 141 & 95.9 & 291 & 94.5 & 0.650 & 0.420 \\
\hline Disinfects the instruments & 117 & 72.7 & 120 & 81.6 & 237 & 76.9 & 2.990 & 0.084 \\
\hline Only washes the used instruments & 103 & 64.0 & 69 & 46.9 & 172 & 55.8 & 8.370 & $0.004^{*}$ \\
\hline Washes hands & 104 & 64.6 & 90 & 61.2 & 194 & 63.0 & 0.240 & 0.621 \\
\hline Wears prote ctiveclothes/or gloves & 85 & 52.8 & 14 & 9.6 & 99 & 32.1 & 64.00 & $0.001^{*}$ \\
\hline \multicolumn{9}{|l|}{ Disinfectant used } \\
\hline Perfume & 82 & 50.9 & 46 & 31.3 & 128 & 41.6 & 11.41 & $0.001^{*}$ \\
\hline Savlon $^{\circledast}$ & 79 & 49.1 & 47 & 32.0 & 126 & 40.9 & 8.60 & $0.003^{*}$ \\
\hline Alcohol & 61 & 37.9 & 50 & 34.0 & 111 & 36.0 & 0.35 & 0.556 \\
\hline Talcum powder & 34 & 21.1 & 7 & 4.8 & 41 & 13.3 & 16.42 & $0.001^{*}$ \\
\hline Povidone/iodine & 14 & 8.7 & 15 & 10.2 & 29 & 9.4 & 0.07 & 0.797 \\
\hline Hydrogen peroxide & 17 & 10.6 & 2 & 1.4 & 19 & 6.2 & 9.70 & $0.002^{*}$ \\
\hline Dettol $^{\circledast}$ & 8 & 5.0 & 9 & 6.1 & 17 & 5.5 & 0.04 & 0.847 \\
\hline Water & 4 & 2.5 & 5 & 3.4 & 9 & 2.9 & $\mathrm{FE}$ & 0.741 \\
\hline Alum crystals (shaba) & 1 & 0.6 & 4 & 2.7 & 5 & 1.6 & $\mathrm{FE}$ & 0.196 \\
\hline None & 3 & 1.9 & 3 & 2.0 & 6 & 1.9 & $\mathrm{FE}$ & 1.000 \\
\hline Changes disinfectant frequently & 91 & 56.5 & 89 & 60.5 & 180 & 58.4 & 0.36 & 0.549 \\
\hline
\end{tabular}

${ }^{*} P<0.05$.

More than 1 answer was reported.

$F E=$ Fisher exact test.

suppression could increase the persistence of viraemia following acute infection with both $\mathrm{HBV}$ and $\mathrm{HCV}$ and this could partly explain the high prevalence of HCV infection in Egypt $[18,19]$. However, no association was observed between HCV and Schistosoma mansoni infection in endemic areas in either Egypt or Brazil [20,21].

Many workers consider infection with HBV and HCV to be an occupational hazard for barbers $[10,22]$. Other researchers consider barbers a source of infection to their clients, especially when there is reuse of razor blades that may transmit infection through micro-trauma $[23,24]$. However, others found no relation between shaving by community barbers and infection with viral hepatitis [5]. Özdemir et al. concluded that HBV and HCV infections are not occupational risks for barbers and hairdressers [24]. The same can be concluded from the results of the present study, as the rate of viral hepatitis infection among barbers was the same as that among their regular clients and was similar to the prevalence in the general population in Egypt $[4,5,16]$. This is consistent with our finding that barbers and their clients were not generally being exposed to risk factors for $\mathrm{HBV}$ and $\mathrm{HCV}$ infection

\begin{tabular}{|c|c|c|c|c|c|c|c|c|}
\hline \multirow[t]{3}{*}{ Practice item } & \multicolumn{4}{|c|}{ Clients' residence } & \multirow{2}{*}{\multicolumn{2}{|c|}{ Total $(n=308)$}} & \multirow[t]{3}{*}{$x^{2}$-value } & \multirow[t]{3}{*}{$P$-value } \\
\hline & \multicolumn{2}{|c|}{ Urban $(n=161)$} & \multicolumn{2}{|c|}{ Rural $(n=147)$} & & & & \\
\hline & No. & $\%$ & No. & $\%$ & No. & $\%$ & & \\
\hline Verifies the status of instruments & 130 & 80.7 & 89 & 60.5 & 219 & 71.1 & 14.29 & $0.001^{*}$ \\
\hline Asks if the instruments has been disinfected & 58 & 36.0 & 65 & 44.2 & 123 & 39.9 & 1.82 & 0.177 \\
\hline Asks barber to disinfect the instruments & 72 & 44.7 & 74 & 50.3 & 146 & 47.4 & 0.76 & 0.383 \\
\hline Refuses shaving with used instruments & 53 & 32.9 & 106 & 72.1 & 159 & 51.6 & 45.70 & $0.001^{*}$ \\
\hline Brings his own instruments & 44 & 27.3 & 23 & 15.6 & 67 & 21.8 & 5.49 & $0.019^{*}$ \\
\hline Asks barber to wash his hands before shaving & 30 & 18.6 & 12 & 8.2 & 42 & 13.6 & 6.29 & $0.012^{*}$ \\
\hline
\end{tabular}

${ }^{*} P<0.05$. 


\begin{tabular}{|c|c|c|c|c|c|c|c|c|}
\hline \multirow[t]{2}{*}{ Observation items } & \multicolumn{2}{|c|}{$\begin{array}{l}\text { Urban } \\
(n=161)\end{array}$} & \multicolumn{2}{|c|}{$\begin{array}{c}\text { Rural } \\
(n=147)\end{array}$} & \multicolumn{2}{|c|}{$\begin{array}{c}\text { Total } \\
(n=308)\end{array}$} & \multirow[t]{2}{*}{$x^{2}$-value } & \multirow[t]{2}{*}{$P$-value } \\
\hline & No. & $\%$ & No. & $\%$ & No. & $\%$ & & \\
\hline \multicolumn{9}{|l|}{ Barber shop } \\
\hline Has adequate electric supply & 116 & 72.0 & 127 & 86.4 & 243 & 78.9 & 8.65 & $0.003^{*}$ \\
\hline Has adequate ventilation & 112 & 69.6 & 130 & 88.4 & 242 & 78.6 & 15.15 & $0.001^{*}$ \\
\hline Has ceiling fans/airconditioning & 112 & 69.6 & 123 & 83.7 & 235 & 76.3 & 7.70 & $0.005^{*}$ \\
\hline Is clean and neat & 110 & 68.3 & 110 & 74.8 & 220 & 71.4 & 1.29 & 0.256 \\
\hline Has adequate sinks for washing hands and face & 109 & 67.7 & 110 & 74.8 & 219 & 71.1 & 1.57 & 0.210 \\
\hline Has good washing facilities & 89 & 55.3 & 65 & 44.2 & 154 & 50.0 & 3.33 & 0.068 \\
\hline Is decorative/attractive & 97 & 60.2 & 56 & 38.1 & 153 & 49.7 & 14.21 & $0.001^{*}$ \\
\hline Situated on main road & 67 & 41.6 & 61 & 41.5 & 128 & 41.6 & 0.01 & 0.924 \\
\hline Situated in internal market area & 44 & 27.3 & 31 & 21.1 & 75 & 24.4 & 1.30 & 0.253 \\
\hline \multicolumn{9}{|l|}{ Barber's practices during shaving } \\
\hline Uses razor machine & 154 & 95.7 & 119 & 81.0 & 273 & 88.6 & 15.06 & $0.001^{*}$ \\
\hline Throws used blades in waste bin & 137 & 85.1 & 126 & 85.7 & 263 & 85.4 & 0.02 & 0.877 \\
\hline Properly disinfects skin cuts & 123 & 76.4 & 119 & 81.0 & 242 & 78.6 & 0.70 & 0.404 \\
\hline Washes razor with antiseptic & 122 & 75.8 & 95 & 64.6 & 204 & 66.2 & 4.07 & $0.044^{*}$ \\
\hline Sterilizes the razor before use for each client & 85 & 52.8 & 89 & 60.5 & 174 & 56.5 & 1.58 & 0.209 \\
\hline Causes cuts from razor machine & 118 & 73.3 & 56 & 38.1 & 174 & 56.5 & 37.31 & $0.001^{*}$ \\
\hline Uses alum as antiseptic for skin cuts & 99 & 61.5 & 61 & 41.5 & 160 & 51.9 & 11.52 & $0.001^{*}$ \\
\hline Uses new razor for each client & 86 & 53.4 & 118 & 80.3 & 135 & 43.8 & 23.59 & $0.001^{*}$ \\
\hline Puts used blades in the box & 62 & 38.5 & 33 & 22.4 & 95 & 30.8 & 8.55 & $0.003^{*}$ \\
\hline Washes razor with tapwater only & 23 & 14.3 & 16 & 10.9 & 39 & 12.7 & 0.53 & 0.468 \\
\hline
\end{tabular}

${ }^{*} P<0.05$.

and that knowledge and practices were good among a considerable percentage of barbers.

In our study, the level of knowledge among barbers and their clients was relatively high, especially regarding modes of transmission. But there were information deficits about the complications and treatment of hepatitis, perhaps because friends and relatives were an important source of information. Studies carried out in Morocco, Ethiopia and Pakistan showed that the level of knowledge and awareness of barbers about the concept of infectious risk associated with blood was generally very low, especially for $\mathrm{HBV}$ and $\mathrm{HCV}$ $[14,25,26]$. Poor knowledge and lack of awareness of the general public about $\mathrm{HBV}$ and HCV is the main cause of the rapid spread of these infections in developing countries compared with developed ones [26,27].

In previous studies, it was found that the proportion of barbers with a positive attitude to the risk of virus transmission was greater than the proportion of those with good knowledge and good practice $[22,25]$. The present study showed that there were positive attitudes towards safe injections and use of antiseptics, especially among clients. The practices of barbers were also generally sound, as similarly documented in Pakistan [27]. However, the practice of throwing used blades in the waste bin poses a major risk to garbage handlers and waste scavengers, who in Egypt and other developing countries commonly search the waste dumps for valuable items and metals and are also likely to be children.
The majority of barber shops in Gharbia governorate had good hygiene conditions, whereas Zahraoui-Mehadj et al. reported that hygienic conditions were deficient among barbers in Morocco [15].

There were some limitations to the study. The sample size of barbers was chosen to be representative of all barbers in the studied areas. However, the sample size of clients was small and not fully representative of all clients. Thus the study gives only a general picture of the situation among clients.

\section{Conclusions}

This study revealed a very similar infection rate of HBV and HCV among barbers and their clients to that reported nationally. The prevalence of HBV and 
HCV among barbers was similar to that among clients. Barbers appeared to have no job-related risk of acquiring viral hepatitis. This may be due to the relatively good knowledge among barbers about modes of transmission and positive attitude towards protecting themselves and their clients and also due to good practices by the majority of the studied barbers and good hygiene conditions in barber shops.

\section{Acknowledgements}

This study received technical and financial support from the joint $\mathrm{WHO}$ Eastern Mediterranean Regional Office
(EMRO), Division of Communicable diseases (DCD) and the WHO Special Programme for Research and Training in Tropical Diseases (TDR): the EMRO/TDR Small Grants Scheme for Operational Research in Tropical Medicine and other Communicable Diseases.

\section{References}

1. Hepatitis B. Geneva, World Health Organization, 2000 (WHO Fact sheet, no. 204).

2. Hepatitis C. Geneva, World Health Organization, 2000 (WHO Fact sheet, no. 164).

3. Alter MJ. Epidemiology of hepatitis C virus infection. World journal gastroenterology, 2007, 13(17):2436-41

4. Abdel-Aziz F et al. Hepatitis C virus (HCV) infection in a community in the Nile Delta: population description and HCV prevalence. Hepatology, 2000, 32(1):111-5.

5. Medhat $\mathrm{A}$ et al. Hepatitis $\mathrm{C}$ in a community in Upper Egypt: risk factors for infection. American journal of tropical medicine and hygiene, 2002, 66(5):633-8.

6. El-Sayed NM et al. Seroprevalence survey of Egyptian tourism workers for hepatitis B virus, hepatitis C virus, human immunodeficiency virus, and Treponema pallidum infections: association of hepatitis $C$ virus infections with specific regions of Egypt. American journal of tropical medicine and hygiene, 1996, 55(2):179-84.

7. Abdel-Wahab MF et al. High seroprevalence of hepatitis $C$ infection among risk groups in Egypt. American journal of tropical medicine and hygiene, 1994, 51(5):563-7.

8. Angelico $\mathrm{M}$ et al. Chronic liver disease in the Alexandria governorate, Egypt: contribution of schistosomiasis and hepatitis virus infections. Journal of hepatology, 1997, 26(2):236-43.

9. Mariano A et al. Role of beauty treatment in the spread of parenterally transmitted hepatitis viruses in Italy. Journal of medical virology, 2004, 74(2):216-20.

10. Mele A et al. Beauty treatments and risk of parenterally transmitted hepatitis: results from the hepatitis surveillance system in Italy. Scandinavian journal of infectious diseases, 1995, 27(5):441-4.

11. Sawayama $\mathrm{Y}$ et al. Hepatitis $\mathrm{C}$ virus infection in institutionalized psychiatric patients: possible role of transmission by razor sharing. Digestive diseases and sciences, 2000, 45(2):351-6.

12. Intercountry workshop on the prevention and control of viral hepatitis. Alexandria, World Health Organization Regional Office for the Eastern Mediterranean, 1995.

13. Candan F et al. Prevalence of hepatitis B and C virus infection in barbers in the Sivas region of Turkey. Occupational medicine, 2002, 52(1):31-4.

14. Zahraoui-Mehadji M et al. Risque infectieux lie au sang chez les coiffeurs-barbiers traditionnels et leurs clients au Maroc [Infectious risks associated with blood exposure for tradi- tional barbers and their customers in Moroccol. Santé, 2004 14(4):211-6.

15. Qirbi N, Hall AJ. Epidemiology of hepatitis B virus infection in the Middle East. Eastern Mediterranean health journal, 2001, 7(6):1034-45.

16. Nafeh $\mathrm{MH}$ et al. Hepatitis $\mathrm{C}$ in a community in Upper Egypt: 1 Cross-sectional survey. American journal of tropical medicine and hygiene, 2000, 63(5-6):236-41.

17. Rao MR et al. Further evidence for association of hepatitis $C$ infection with parenteral schistosomiasis treatment in Egypt. BMC infectious diseases, 200, 2:29.

18. Ghaffar YA et al. The impact of endemic schistosomiasis on acute viral hepatitis. American journal of tropical medicine and hygiene, 1991, 45:743-50.

19. El-Zayadi AR. Curse of schistosomiasis on Egyptian liver. World journal of gastroenterology, 2004, 10(8):1079-81.

20. Blanton RE et al. Population-based differences in Schistosoma mansoni- and hepatitis C-induced disease. Journal of infectious diseases, 2002, 185(11):1644-9.

21. Tavares-Neto J et al. Very low prevalence of hepatitis $C$ virus infection in rural communities of northeastern Brazil with a high prevalence of schistosomiasis mansoni. Revista da Sociedade Brasileira de Medicina Tropical, 2005, 38(4):290-3.

22. Janjua NZ, Nizamy MAM. Knowledge and practices of barbers about hepatitis B and C transmission in Rawalpindi and Islamabad. Journal of the Pakistan Medical Association, 2004, 54(3):116-9.

23. Rashid H, Shafi S. Blood borne hepatitis at Hajj. Hepatitis monthly, 2006, 6(2):87-8.

24. Özdemir L et al. Sivas ilinde berber ve kuaförlerde HBV, HCV ve HIV seroprevalansi [The seroprevalence of HBV, HCV and HIV among barbers and hairdressers in the city center of Sivas]. Cumhuriyet Üniversitesi Tıp Fakültesi, 2004, 26(4):153-6.

25. Zewudie T, Legesse W, Kurkura G. Knowledge, attitudes and practices among barbers in south-western Ethiopia. African newsletter on occupational health and safety, 2002, 12(3):69-71.

26. Khuwaja AK, Qureshi R, Fatmi Z. Knowledge about hepatitis B and $\mathrm{C}$ among patients attending family medicine clinics in Karachi. Eastern Mediterranean health journal, 2002, 8(6):787-93.

27. Chaudhary Al et al. Seroprevalence of hepatitis-B and C among the patients reporting in surgical OPD at Fauji Foundation Hospital, Rawalpindi: review of 5 year literature. Pakistan journal of medical sciences quarterly, 2007, 23(4):514-7. 